\title{
HARRIS AND THE SACRED COW: A CRITIQUE ON MARVIN HARRIS' MATERIALISTIC THEORY ON THE HINDU INDIA' HOLIEST ANIMAL
}

\author{
Prem K Khatry
}

\section{INTRODUCTION}

To the millions of Hindus at home in India and beyond the cow is a highly revered animal. Man shares her milk along with her calf as if he were a calf himself. He would not rear a cow for any other motive such as supply of meat. Rearing and worshipping a cow is an act of piety- dharma- be it a milch or barren, young or old, healthy or diseased. The cow links the world of the mortal with the world of the dead. A house with a cow is a blessed and the most cherished dwelling. Blessed therefore is also the human being who rears a cow. This short article seeks to analyze the theory of the famous anthropologist Marvin Harris on the most sacred animal- the cow- of India.

I will divide this paper into three basic parts and a conclusion as follows:

(1) Introduction to the problem- outline of Harris' arguments

(2) Arguments in favor of Harris' Theory

(3) Criticism of Harris' Theory

(4) Conclusion

\section{HARRIS'S THEORY ON THE SACRED COW}

This outline of Harris' theory on the cow in India and the controversy built around it is primarily drawn from the following sources: "The Sacred Cow Myth" (Man, Culture and Animals, 1965:217-22 ), "The Cultural Ecology of India's Sacred Cattle" Current Anthropology, 7:51-66), "Mother Cow" (Cow, Pigs, Wars and Witches, 1975), the chapter of his latest book "Cultural Materialism" (1974:242-256), and Alan Heston's article "An Approach to the Sacred Cow of India" (Curr. Anth., 12:191-209).

In the contemporary American anthropological tradition, Marvin Harris maintains a highly controversial position of a cultural materialist and is often surrounded by severe criticism because of his materialist theory and unproved, speculative ideas. Friedman's terms 'vulgar materialism' is the extreme expression of those who find Harris' argument not only speculative, but also highly distorted. Harris' materialist interpretation of India's cattle population, especially the functional use of cows in India, literally ignited a prolonged debate that is far from being settled. Although Harris' opinion of Indian cows appeared first in 1965, the much discussed, provocative and controversial thesis on the subject came in 1966 (Current Anth, 7:51-66). The two other articles mentioned in the beginning section 


\section{HARRIS AND THE SACRED COW}

of this paper are but the edited and additional versions of the 1965 and the 1966 articl

In the article "The Cultural Ecology of India's Sacred Cattle", Harris collects the opinions of several western and western trained Indian scholars regarding the economic deficiency the animals are causing in the name of the sacred value of the cows in the Hindu religious tradition. Summarized, the opinions are: India's excess, useless cattle population has a very negligible economic value, and the ever-growing number of cattle poses a burden on man as well as a threat to man's balance with his resources. religious prejudices against killing of cows are basically responsible for such growth of the cattle population in India. This situation makes planned improvement of breeding and the adequate supply of fodder impossible, hence, the cattle population continues to grow far beyond the economic requirement of the nation.

Harris vehemently rejects this evaluation of cow situation and its threat on Indian economy. He has put forward an ecological interpretation to explain the role of cows in India. His cow theory originated against the western and the westerneducated India scholars' prejudices' (such as mentioned above). It is one of the several areas in which he sought the rationale of cultural practices to show how different culture have adapted to their different local socio-economic settings (Harris 1975:126). His use of the term cultural ecology involves wide system involving men, land, crops, technology, animals and the physical environment where both men and animals have symbiotic relationship within the ecosystem. On this particular topic, his discussion is based on the following basic premises.

(1) There are no excess cattle in India

(2) Religious faith is not the primary reason behind the anti-slaughter tradition, it is (Darwinian) ecological pressure that is at work.

(3) Everything remaining equal, an environment and a culture configuration will reach an equilibrium over a period of time; any change in one system causes change in the whole.

\section{MERITS OF HARRIS' THEORY}

As most critics agree, Harris picked a provocative, sensational topic that aroused the attention and interest of many scholars working in different fields ranging from anthropology to geography, economic and sociology. As John Bennett argues (1977:197), one major outcome of Harris' sacred cattle thesis is that it brought anthropology and economics together into a continued dialogue on issues of general interest and significance. This, then, could be considered Harris' first contribution.

So far Harris' theory itself is concerned, there are very few points that could be made in support of his argument on the role of cows in the predominantly agricultural Indian society. Although he denies the correlation between cowreverence and the growth of cow population and protection, he implies that such a reverence originated once the cow's important role in the ecological system was 
realized (1979:253). In a way, Harris couples together both the material and the moral world by arguing that moral practice came as a corollary to the material interest, considering the religions position given the cow, his argument is not tenable. However, he concedes that there is some sort of religious veneration that the Hindus display toward the cow.

Harris also argues there is always a shortage of draught animals in India. In other words, not all the 60 million Indian farmers have a pair of bullocks essential for ploughing their farm and carrying out several other tasks. In tropical India, where major crop cultivation depends on monsoon rains, all farmers have to begin and complete their cultivation simultaneously and a bullockless farmer cannot expect to borrow oxen to plow his land. Because bullocks, are the only source of energy, those who lack them, face possible starvation. This argument presented in Harri's writing (1966:53) is not controversial.

From a methodological point of view, part of Harris hypothesis is testable. One can take it to the field and text. For example, he outlines the contribution of cows in terms of traction, milk, dung, and hide. Every Indian would agree that this is correct, although beef is eaten only by one caste and few other communities. Harris also thinks the economic theory developed to explain western market economy does not work in explaining the Indian situations which are totally different from the western picture.

Finally, onc more point could be made in favour of Harris' theory. The cowreverence model is hard to measure. As Harris says, under extreme physical pressure the cow-revering Hindus have resorted to beef eating several times in the past and it is so even today. Harris however does not specify which castes were or are involved in these practices.

\section{CRITICISM OF HARRIS' THEORY ON COW}

Harris' sacred cow theory has been vulnerable on many groundsconceptual, logical and factual. Harris has tried to make his case strong by putting together his own subjective observation and those of some other writers and field researchers. But none of the other writers fully subscribe to his cultural materialistic interpretation that, Harris admits, deals with probabilistic causes (1979:242). Most of the criticisms regarding the cow controversy are directed to the theoretical reasoning that he applied in interpreting several complex cultural practices prevalent in different part of the world.

In the introductory section of the paper, I have mentioned three basic premises that Harris has raised in the discussion of his theories on Indian cows. Here I will examine them individually.

\section{THE ISSUE OF EXCESS CATTLE POPULATION}

Harris' major attack on the critics is on the issue of the cow population in India. He outright rejects the arguments that there was or has ever been any excess population in India. He thinks that the observers of western, industrialized nations 
do not see the symbiotic or dependent nature of relationship between man and the

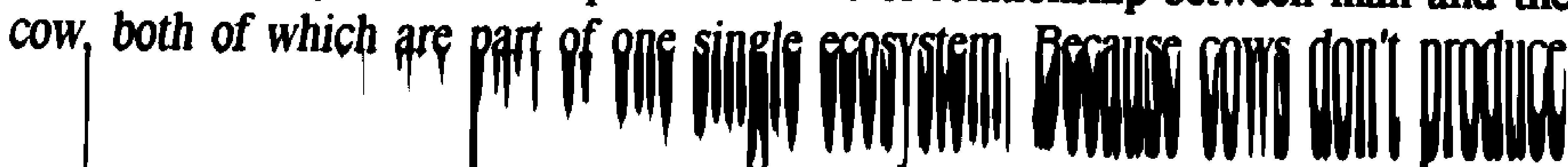

energy in the west as they do in India, those who fail to realize this, see the cows as surplus and useless animals. They assert that cows are surplus because they don't play a direct role in economy. As many as $\mathbf{3 0}$ million of them provide neither milk nor meat. But Harris sees the situation quiet differently. He argues that for sixty million Indian farms, there are only eighty million oxen, thus showing a shortage of forty million plow animals (1974:12). Besides that milk and dung are equally important; milk is a source of food and dry dung is used as a cooking fueld all over nural India thus saving sixty-eight millions of firewood every year (Parrack, 1969:38).

There cannot be a stronger controversy than that regarding the man-cow relationship in agrarian India. The Cow's role in agriculture cannot be undermined. But, several studies have shown that there actually is an excess of cattle in India, chiefly because they are regarded as unslaughterable and that there is no planned breeding to control the population and improve the product. More than anything else, this situation makes male cow ratio unbalanced and the nourishment of the cattle impossible. Alan Heston did a survey research on the problem. To use Heston's figure (1971:194), in 1971 the adult male cow population there was 72.5 million. Heston argues that in a normal healthy condition, a mature female cow can give birth to an support at least six claves. Assuming that at least three calves are male, the necessary number of female cow, Heston shows, is 24 million as against the 1971 figure of 54 million. Considering that $\mathbf{7 2 . 5}$ million figure is inadequate for the reported 60 million farms, 54 million female cows, are still far more than the required number and the feeding capacity of the resources.

The excess cow population, both directly and indirectly, influences day to day life in India, Because man and cow are part of the same ecosystem, there is obvious competition of survival but Harris refuses to acknowledge this competition Five percent of India's total arable ; and is used for cattle fodder. The cows need vast grazing field. Contrary to Harri's arguments, a rural cow does not depend on scavenging as long as other resources are available. Besides that the cows contribute along with other animals, to the destruction of ripe grain. The annual figure of such destruction is estimated at $\mathbf{4 0 - 4 5 \%}$ of the total grain production. Even in Harri's opinion (1975:20), cow consume $20 \%$ of man's food. Converted into nupees, all such wastes could amount to billions very year (Heston 1971:192). To reject the 'excess' theory, Harries compares the man-cow ratio in India with that in countries like the US. and Canada, where such ratio is higher than India, But, it should be noted that in those countries, the cow is the only major source of meat, and meat is major diet. Moreover, the population density in the United states and Canada is sucin less in comparison to that in India. So the 100:49 man-cow ratio in India is still high considering the exploding human population and growing need for more grain production.

Another fact related to the man-cow ratio is the location of the cattle population. In India, a large segment of human population in cities whereas cattle 
population is concentrated in the rural areas. Considering the 100:49 ratio, it is clear that the man-cattle ratio is much higher and the completion much tougher in rural India, where cattle cause serious damage to crops and become a burden to men. Haris' argument is that in several cities the freely roaming cows get temporary shelter and good food even when they are captured and put into rest houses till the owner comes to find them. In most cases, the owners deliberately loose the cow to let them wander in search of food. In other cases, the owners don't have enough shelter for the animals. This is a usual practice in many urban-suburban areas. This does not solve problem of the excess cow population and the damage it is causing. Further, this can only raise other problems. In urban and the suburban areas, the vagabond cattle pose a serious threat to safety, and tolerance is the only solution the people have.

\section{RELIGION AND THE COW}

As mentioned in the beginning section, Harris holds that it is not the influence of religious faith that is responsible for the protection of cows. He argues that cow produce traction animals, milk and dung and when they die, they provide food for one untouchable caste. The veneration of cows is a corollary to their ecological role in maintaining a balance between resources and the human-animal organism. The Indian farmer has to choose between long-term survival and his immediate needs. In other not to face starvation, he does not slaughter but saves the cow. Even if it is baren, it is a source of energy and is also his defence against his money lender (Harris: 1974:19).

Most of Harri's arguments are simplistic. Actually, in an unplanned and over populated herd of cows, there is always the likelihood of several female cow's dying early or remaining barren for life. Alan Heston's research (1971:193) indicates that there is a clear-out tendency toward the death of young female cows. Those that survive to calve are not good milkers, if they calve at all. This fact is accepted by Harris and others. The only economic advantage of holding the herds of cow be the cow dung. Considering the minimum food and care needed to keep the animal, the value of cow dung per animal is negligible. Moreover, it is not possible to collect all the droppings and utilze them as cattle are mobile animals. But, a farmer maintains the herd, to him the animals are like the family members. He does not always calculate the economic return. The aspects of cow-love and reverence become clearer if one analyses this phenomenon. Harris' general information led him to believe that the present number of cows is less than is required, and that the Indian farmer realizes the shortage. In fact, the farmer knows that a barren cow can be neither a defensive weapon against his money lender, nor can the old cows be of any economic use. Nothing can be held responsible for such a situation except the age old Hindu religious tradition against physically harming cows. As I have mentioned elscwhere in this paper, the Hindu regions of India tend to maintain a large number of female cows as compared to the non-Hindu regions except where cow is a working animal. If utility was the only motive of the Indians for having the cow, then buffalo could be the best choice for milk, dung, traction and hide. But the buffaloes has not replaced the cow even in regions where the cows' role in milk 
production is secondary to the buffalo's. Moreover, buffaloes are equally adaptive to

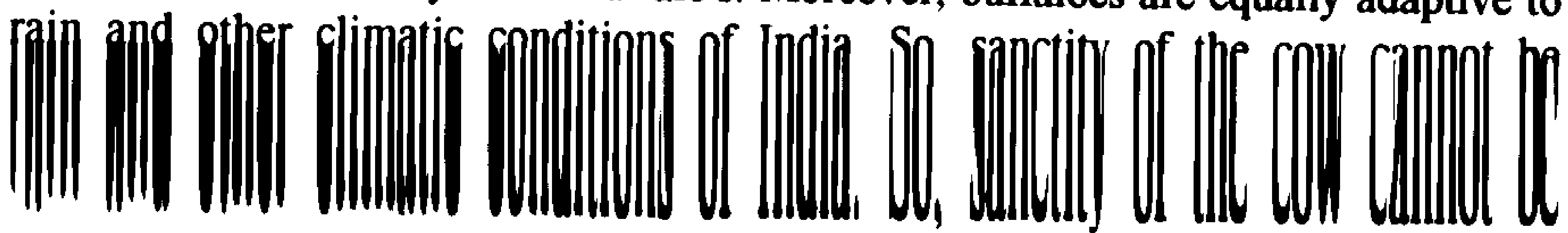

considered a weak variable for explaining the cow situation in India despite the fact that Harris suggests so.

\section{THE EQUILIBRIUM QUESTION}

The main emphasis of Harris' argument is on the 'practical and rational' side of the cow-reverence in India. To him, cow love is not emotional but rather is practical, and he has sought to apply his evolutionary explanation to solve the controversial problem. He considers western attitudes on the cow question from a western agribusiness economy viewpoint. He argues that from an energy utilization point of view, the traditional Indian society is doing much better than the US. He sees a materialist, not a spiritual, relationship between man and the cow, a relationship that results in adaptive cultural mechanisms and behaviour. That is, such behaviour is the product of different material conditions and environmental relationship. Cow protection in India thus has an adaptive economic utility as a ecological pressure for equilibrium. He also thinks that the Vedic Hindus killed the cow and ate beef freely. But once they realized the economic importance of the cow, they placed a tabu on slaughtering cows (1979:253).

Like the two other premises mentioned above, this one is also based on Harris' speculative ideas. His theory of equilibrium suggests that a certain population maintains its size in keeping with the carrying capacity of its physical resources. Any other form of behaviour can upset the balance between the population and environment. But, this concept (in the present context) is weak in the sense that one element of behaviour cannot be regarded as having adequate adaptive value only by virtue of being a part of the system. In no way do the barred, old and useless cattle contribute to maintaining a balance between man and environment. As has been discussed earlier the cattle, in fact, are unmanaged and often become a social nuisance and economic burden to the farmers. This is because despite their uselessness, the Hindu farmer can not voluntarily send them to the slaughter house. In his research Heston found female cow ratio higher in the nonHindu regions where female cows are used as plow or working animals. In other regions, where oxen are more important as plow animals, the female cow population is lower that the male cow population. On the other hand, in the Hindu religions. where only the male is the work animals, the female con population is lower than the male cow population. On the other hand, in the Hindu regions, where only the male is the work animal, the female population is till higher than the working malc population (Heston 1971:196). None of these facts show that the half-stancd, wcak and unplanned cow population plays any significant role in the ccosystem of India.

\section{CONCLUSION}

Harris' arguments that all the cattle of India have played an important economic role as part of the total ecological system are not acceptable. Although onc could argue that killing cows is one way of getting casy and chcap protein and of providing cnough food for the undernourished cattle, the slaying of cows is not 
sensible solution to the problem of cow population either. The cow population goes on increasing spontaneously and it does not serve any ecological or economic purposes as the total cow population has to be fed to the determent of the milk cow and the working animal. Further, this situation causes the decrease in productive potential on the part of the male working animal and the mothering cow. It is not a balanced, but rather an imbalanced situation. It will be relevant here to discuss in brief Alan Heston's economic model presented in his 1971 article. His first suggestion, to slaughter the thirty million extra cows (1971:191) is too insensitive and impractical. In the present situation, no Hindu would be ready to do so. But, his model has some practical and feasible sides in it. For example, he talks about a possible planned situation that could be adopted to control; the cattle population, save fodder, improve breeding and milk production without slaughtering cattle. Today's large cow population is, in fact, not adaptive to the actual needs of the farmer, but it is the result of uncontrolled breeding and the Hindu sentiment against slaughtering of the cow. The planned cattle population would free a vast amount of grazing land for cultivation. At the present time, man and cow have been competing for the green pastures and the cultivated land. That is one aspect of the total cattle picture.

Harris' arguments imply that since the general economic situation farm size and the laws regarding land holding and ownership are not likely to go through a rapid radical change, a pair of oxen and calf-bearing cow are the basic needs of the Indian farmer at the present time. No one would disagree with Harris on these basic simple facts. Harris is also right when he says that India is a nation of family farms. So, unless the above mentioned social and economic factors are changed and suitable alternatives are made available to the farmer, the low-energy animal will keep the plow moving. The major problem, however, is to make adequate food, shelter and care available to the cattle so as to get maximum utility from the animals (to provide traction animals, milk, dung, and hide in Harris' terms). This can be achieved only by controlling the growth of excess cattle that has gone beyond the feeding means of the environment. Finally, whatever Harris' arguments about the adaptive nature of the cow protection, it is an example of the relationship between traditional values and the practices. Harris has repeatedly claimed that he found the practical answer to the puzzling questions of the sacred cow, whose sacredness is thus related to man's subsistence need. But, as Dr. Orans (1975:328) has remarked Harris does not provide a correlation between the sacredness of the cow and the subsistence needs. It is rather evident that man has not only adapted to the physical environment, but rather he has also adapted to his traditional beliefs. Holding the burden of an undesirable number of cattle is proof of the latter type of adaptation. So, although Harris' theory on cow is interesting, it is not a sound basis for supporting the super-structure of his cultural materialism.

\section{WORKS CITED}

Harris, Marvin (1965), The Myth of the Sacred Cow, In Man, Culture and Animals. Anthony Leeds and Andrew P. Vayda, eds. Washington, D.C.: American Association for the Advancement of Science, pp. 217-228. 


\section{HARRIS AND THE SACRED COW}

(1966), The Cultural Ecology of India's Sacred Cattle. Current Anthropology, 7:51-66.

(1975), Cow, Pigs, Wars and Witches, The Riddle of Culture. New York: Vintage Books.

(1979), Cultural Materialism, The Struggle for a Science of Culture. New York: Random House.

Heston, Alan (1971), An Approach to the Sacred Cow of India. Currengt Anthropology, 12:191-209.

Orans, Martin (1975), Domesticating the Functional Dragon: Analysis of Piddocke's Potlatch. American Anthropology, 77:321-328.

Parrack, Dwain W. (1969), An Approach to the Bioenergetics of Rural West Bengal, In Environment and Cultural Behavior. Andrew P. Vayda, ed. New York: American Museum of Natural History.

Tietschmann, B. (1975), Cows, Pigs, Wars and Witches (Book Review). Reviews in Anthropology, 2:157-168.

(1971), A Review of Beef in Ancient India. Gorakhpur: Gita Press. 